\title{
Australian Consumers' Response to Insects as Food
}

\author{
Giovanni Sogari ${ }^{1,2, * \mathbb{D}}$, Diana Bogueva ${ }^{3}$ and Dora Marinova ${ }^{3}$ (i) \\ 1 Department of Food and Drug, University of Parma, 43124 Parma, Italy \\ 2 Charles H. Dyson School of Applied Economics and Management, Cornell University, Ithaca, NY 14850, USA \\ 3 Curtin University Sustainability Policy Institute (CUSP), Curtin University, Perth 6102, Australia; \\ diana.bogueva@postgrad.curtin.edu.au (D.B.); d.marinova@curtin.edu.au (D.M.) \\ * Correspondence: giovanni.sogari@unipr.it; Tel.: +39-0521-906545
}

Received: 5 April 2019; Accepted: 17 May 2019; Published: 22 May 2019

\begin{abstract}
Many research articles have been published about people's perceptions and acceptance of eating insects as novel foods in Western countries; however, only a few studies have focused on Australian consumers. The aim of this work is to explore attitudes towards edible insects of younger Australians (Millennials and Generation Z) with data collection carried out in Sydney, Australia. Two representative surveys were conducted in 2018 and 2019 using open-ended questions. The main findings suggest that there is low willingness to accept edible insects as a meat substitute among Australian consumers, due mainly to the strong psychological barriers such as neophobia and disgust, combined with a perception about threats to masculinity. Environmental and nutritional benefits, even when recognised, do not seem to influence consumers to consider insects as a food alternative. In the near future, as young people become more aware of sustainability and climate change issues related to food production, the impact of the potential benefits of insects might grow. Furthermore, a positive sensory experience might improve the acceptability of insects as food. Introducing new processed, insect-based products may help establish familiarity with such novel food options and open up new business opportunities.
\end{abstract}

Keywords: sustainability; edible insects; Australia; Sydney; food; climate change; novel foods; Millenials; Genereration Z; interview; entomophagy; neophobia

\section{Introduction}

The world population is projected to grow from some 7.3 billion today to almost 9.8 billion by 2050 [1], which will consequently increase the global food demand [2,3]. One of the greatest challenges in the sustainability debate is the impact of the food system and our dietary choices on the natural environment $[4,5]$, with an expected further global shift to diets rich in animal products and as a result higher protein demand in the near future [6].

Traditional animal protein sources require more inputs to be produced and often cause greater environmental damage (e.g., greenhouse gas emissions, loss in biodiversity, and other negative consequences for the ecosystem) compared to vegetable-based foods $[7,8]$. Thereby, a quest for more alternative animal protein sources is expected to become a considerable issue in the food supply chain $[9,10]$, with more sustainable novel options to help mitigate climate change [11]. One such new food source, which has already drawn attention in the scientific community, private sector, and among the general public, is edible insects [2,12]. After the 2013 publication "Edible insects, future prospects for food and feed security" by the Food and Agriculture Organization (FAO) of the United Nations [13], a growing interest and an increased number of studies appeared on the potential acceptability of insects as a "food of the future" $[12,14,15]$. In general, insects are considered to have several nutritional benefits such as high content of proteins, unsaturated fatty acids, and micronutrients [16], with a considerable nutrient variation depending on the feed composition used during the rearing process [17]. 
Many studies have also shown that farming insects has a higher feed-conversion efficiency, requiring less space and water, thereby having an overall smaller ecological footprint compared to livestock production $[6,9,18]$. Considering the large number of insect species, farming methods, and possible substrates used [2], further investigation is required from production, safety, and nutritive value points of view $[17,19]$.

From a consumers' perspective, the evidence presented so far suggests that insects might grow in popularity as an alternative protein source, even in Western countries where currently entomophagy is perceived as a custom practiced only by people in extreme poverty and out of necessity $[20,21]$. Insects have been eaten by humans in many parts of the world for millennia and have been consumed at different life-stages using various preparation techniques including raw, fried, boiled, roasted, and ground [4,22]. For instance, according to Meyer-Rochow and Changkija [23], Australian Aborigines belong to the earliest group of insect eaters, with termites, grubs of numerous species of beetles, and moths being among their favourite foods.

Worldwide about 2111 species of insects have been recorded as edible [24] and are currently consumed by approximately two billion people in many ethnic groups, largely located in Asia, Africa, South America, and Australia [13]. However, only a few species have been considered of interest from a commercial application as food in the Western market, namely, Gryllodus sigillatus and Acheta domesticus (house crickets), Alphitobius diaperinus (lesser mealworm), Tenebrio molitor (yellow mealworm), and grasshoppers [12,20].

Many researchers have investigated consumer behaviour towards eating edible insects and related processed insect-based products (for a comprehensive review, see Mancini, Moruzzo, Riccioli, and Paci [25]). However, only a few studies have specifically focused on consumer acceptance, knowledge, and attitude in Australia for young adults [26-28]. More research using qualitative techniques (e.g., open-ended questions) related to consumers'opinions is required to shed light on potential business opportunities for this novel food [29].

This study aims to better understand consumer attitudes towards eating insects and insect-based products among a group of younger Australian residents. We particularly targeted people born between 1977 and 2001, namely, Gen Y Millennials and Gen Z Centennials, which has not been done before for the population of interest.

\section{Insects as Food in Australia}

First of all, in Australia, insects are already allowed to be used as a protein source in the agricultural system as part of the feed for farmed animals under the regulations of the Australian Pesticides and Veterinary Medicine Authority (APVMA) [30]. Globally, in recent years, there has been growing interest in the composition of dietary feeds using insect meals for many different animal species [31]. Further research will allow to better understand the effects of different dietary compositions on the organoleptic properties and quality of the final meat products as well as consumer acceptance [31].

When it comes to people eating insects, even though entomophagy can be considered a traditional practice among Aborigines, many edible insects are legislatively categorised as a novel food in Australia [32]. In particular, the food regulatory system categorises insects into three categories: (1) traditional food; (2) non-traditional food that is non-novel; or (3) authorised novel food [30]. Edible insects listed in the category of non-traditional/not-novel food (i.e., food that does not have a history of human consumption but for which no safety risks have been identified) are: Zophobas morio (super mealworm), Achaeta domestica (house crickets), and Tenebrio molitor (mealworm beetle) [32]. For all other species of insects, if a producer wants to sell them as food products or ingredients, exclusive permission needs to be obtained from Food Standards Australia and New Zealand (FSANZ) [29].

In recent years, there has been a lot of media and marketing activities promoting insects as an alternative source of protein food. The Sydney-based Edible Bug Shop company [33] sells insect-based food products online, in health shops, at popular events (e.g., the Naturally Good Expo and the Royal Show), and through direct sales to restaurants. Many Sydney residents and visitors in the city's central 
area have been offered free samples. An overview of the existing studies carried out so far about consumer perception and acceptance of entomophagy in Australia is presented in Table 1.

One of the first studies to provide participants with an insect product to eat (i.e., roasted cricket and biscuit with insect flour) was done in Australia by Lensvelt and Steenbekkers [26]. Since then, there has been a growing number of studies worldwide that have used sensory testing (e.g., check-all-that apply test, hedonic test, and other techniques) to investigate consumers' acceptance and organoleptic parameters of edible insects as food (e.g., Tenebrio Molitor and house cricket in Caparros Megido et al. [34], house cricket in Sogari, Menozzi, and Mora [35]) and insect-based products (e.g., tortilla chips made with cricket flour in Hartmann and Siegrist [14], insect-based burger in Schouteten et al. [36] and Tan et al. [37]). Most of the results show that a sensorial strategy can foster the willingness to try insects and make people more familiar with such new products. 
Table 1. Overview of the key studies on consumer perception and acceptance of insects as food in Australia and New Zealand.

\begin{tabular}{|c|c|c|c|}
\hline Reference & $\begin{array}{l}\text { Study Type (Country, Method, } \\
\text { Sample Size) }\end{array}$ & Research Objectives & Key Findings/Implications \\
\hline $\begin{array}{l}\text { Bogueva and } \\
\text { Schmidinger } \\
(2019)[38]\end{array}$ & $\begin{array}{l}\text { Country: Australia } \\
\text { Online-based survey }(n=227)\end{array}$ & $\begin{array}{l}\text { Investigate psychological } \\
\text { consumer perception and barriers } \\
\text { regarding different meat } \\
\text { alternatives, including edible } \\
\text { insects }\end{array}$ & $\begin{array}{l}\text { The majority of the participants objected to the practice of insect eating, } \\
\text { which is considered not natural and evokes disgust. Most people } \\
\text { discussed the insect dilemma as a choice or necessity. The authors } \\
\text { suggest that the use of different names for insect-based food products } \\
\text { as well as their preparation might decrease the level of disgust, thus } \\
\text { increasing the general willingness to try them. }\end{array}$ \\
\hline $\begin{array}{l}\text { Castro and } \\
\text { Chambers IV } \\
(2018)[39]\end{array}$ & $\begin{array}{l}\text { Country: Australia and } 12 \text { other } \\
\text { countries worldwide International } \\
\text { survey } \\
(n=630 \text { per country) }\end{array}$ & $\begin{array}{l}\text { Determine the impact of adding } \\
\text { insect-based products to a } \\
\text { brand's portfolio }\end{array}$ & $\begin{array}{l}\text { The authors found that in Australia, the disgust factor might affect or } \\
\text { impact brand equity. People most likely will stop buying products } \\
\text { from companies knowing that insect powder has been used in another } \\
\text { product from the same brand. Other barriers to acceptance were } \\
\text { religion, as well as the perception that insects carry diseases and cause } \\
\text { allergic reactions. }\end{array}$ \\
\hline Chan (2019) [40] & $\begin{array}{l}\text { Country: Australia } \\
\text { Three studies } \\
(n=202 ; n=155 ; n=204)\end{array}$ & $\begin{array}{l}\text { Examine the possible impact of } \\
\text { mindfulness on the willingness to } \\
\text { try insect-based foods }\end{array}$ & $\begin{array}{l}\text { The results suggest that mindfulness (that is, the state of being aware) } \\
\text { may increase the disgust and lower the willingness to try eating insects. }\end{array}$ \\
\hline $\begin{array}{l}\text { Lensvelt and } \\
\text { Steenbekkers } \\
(2014)[26]\end{array}$ & $\begin{array}{l}\text { Country: Australia and the } \\
\text { Netherlands } \\
\text { Online survey, choice and tasting } \\
\text { experiment (survey } n=209 \\
134+75 \text {, experiment } n=133 \text { ) }\end{array}$ & $\begin{array}{l}\text { Understand the main factors } \\
\text { involved in consumers' attitudes } \\
\text { toward eating insects }\end{array}$ & $\begin{array}{l}\text { Participants were not aware of the benefits of entomophagy, however, } \\
\text { notably, they liked the taste of roasted crickets and biscuits with insect } \\
\text { flour. The results indicate that information is seen as trustworthy when } \\
\text { provided by scientific researchers, people using the product, the } \\
\text { government and well-known relatives, but not when it is promoted by } \\
\text { food producers or famous persons. }\end{array}$ \\
\hline $\begin{array}{l}\text { Myers and } \\
\text { Pettigrew (2018) } \\
{[27]}\end{array}$ & $\begin{array}{l}\text { Country: Australia } \\
\text { Interviews }(n=77)\end{array}$ & $\begin{array}{l}\text { Explore the attitude towards } \\
\text { entomophagy among senior } \\
\text { people (60 years and over) }\end{array}$ & $\begin{array}{l}\text { Food safety and hygiene might help in accepting insects as food } \\
\text { among older consumers. Appropriate strategies to enjoy the practice } \\
\text { of entomophagy should include teaching how to cook insect dishes. }\end{array}$ \\
\hline $\begin{array}{l}\text { Wilkinson et al. } \\
\text { (2018) [28] }\end{array}$ & $\begin{array}{l}\text { Country: Australia } \\
\text { Online survey }(n=820)\end{array}$ & $\begin{array}{l}\text { Investigate the awareness and } \\
\text { acceptance of insects as food } \\
\text { among Australians }\end{array}$ & $\begin{array}{l}\text { Taste, appearance, and safety were identified as the main factors which } \\
\text { shape the willingness to try eating insects. Food neophobia is } \\
\text { confirmed as one of the main traits in consumer behaviour towards } \\
\text { entomophagy. }\end{array}$ \\
\hline
\end{tabular}




\section{Materials and Methods}

\subsection{Participants}

Two online surveys were conducted in Sydney, Australia in May 2018 and in March 2019, respectively, with 227 and 328 respondents. The participants were randomly recruited from a database of 30,000 Sydney residents who have voluntarily enlisted as willing to participate in surveys, controlling for age (range between 18-40, which are considered members of Gen Y and Gen Z). This is an exploratory qualitative study and no quantitative information was collected except sample demographic attributes and frequencies of meat consumption. The first sample was representative of the Sydney population with a $6.5 \%$ confidence interval width at the $95 \%$ confidence level, while the representativeness of the second sample was improved, with a smaller $5.4 \%$ confidence interval width at the $95 \%$ confidence level.

\subsection{The Questionnaire}

The questions were open-ended with some relevant suggestion probes without restricting the possible answers. This allowed the participants to freely explore and present their views on the topic of edible insects. The questions were clearly formulated and easy to understand in order to ensure participants' interest in engaging with the study and completing the entire questionnaire. The response rates were relatively high: $76 \%$ for the 2018 Survey and 75\% for the 2019 Survey. A response rate of $75 \%$ is considered appropriate to exclude possible bias from both respondents and non-respondents to the survey [41,42].

Participants were required to answer the following questions:

- What is your opinion about edible insects as an alternative food source?

- What may influence you to include edible insects and insect-based products, such as cricket flour or edible insects-filled chocolate bars, in your diet?

The data gathered were in the form of verbatim comments and direct quotations and were analysed both manually using researcher discretion and with the help of the computer-assisted qualitative data analysis software Nvivo11 (QSR International, Victoria, Australia) [43]. The frequencies of occurrence of particular expressions were coded to produce manageable categories describing the factors affecting consumer behaviour in the food domain. Using an adapted version of the model by Marinova and Bogueva [44], which describes the factors impacting consumer behaviour in relation to food choices, the categories were grouped under taste experience, psychological, health, environment, and marketing factors.

\section{Results}

\subsection{Sample Characteristics}

Before analysing the opinions expressed, the main demographic characteristics of the two samples are described (Table 2). In both surveys, there were almost equal proportions of male and female respondents. The two main age groups almost equally represented in the surveys were: 18 to 24 years old who were becoming economically independent and 25 to 40 years old who have already established themselves, particularly in the workplace. In general, the demographic characteristics were representative of the broader Sydney population. We could not identify any major discrepancies which could have alerted us to the presence of a self-selection bias.

Additional descriptive information collected at the beginning of the surveys relates to respondents' frequencies of meat consumption. Meat-eaters (i.e., daily consumers) dominate the two samples, which is representative of the general population and aligns with evidence from other sources, such as the Roy Morgan poll [45]. 
Table 2. Demographic characteristics.

\begin{tabular}{|c|c|c|c|c|c|c|c|}
\hline \multirow{2}{*}{$\begin{array}{l}\begin{array}{c}\text { Demographic } \\
\text { Parameter }\end{array} \\
\text { Gender: }\end{array}$} & \multirow[t]{2}{*}{ Category } & \multicolumn{2}{|c|}{$\begin{array}{l}2018 \text { Survey } \\
(n=227)\end{array}$} & \multicolumn{2}{|c|}{$\begin{array}{l}2019 \text { Survey } \\
(n=328)\end{array}$} & \multicolumn{2}{|c|}{$\begin{array}{c}\text { Total } \\
(n=555)\end{array}$} \\
\hline & & & $\%$ & & $\%$ & & $\%$ \\
\hline & Male & 116 & $51.1 \%$ & 163 & $49.8 \%$ & 279 & $50.4 \%$ \\
\hline & Female & 111 & $48.9 \%$ & 165 & $50.3 \%$ & 276 & $49.7 \%$ \\
\hline \multirow[t]{3}{*}{ Age (years): } & & & $\%$ & & $\%$ & & $\%$ \\
\hline & $18-24$ & 108 & $47.6 \%$ & 158 & $48.2 \%$ & 266 & $47.9 \%$ \\
\hline & $25-40$ & 119 & $52.4 \%$ & 170 & $50.1 \%$ & 289 & $52.1 \%$ \\
\hline \multirow{6}{*}{$\begin{array}{l}\text { Household } \\
\text { income (AUD): }\end{array}$} & & & $\%$ & & $\%$ & & $\%$ \\
\hline & Under $\$ 50,000$ & 24 & $10.6 \%$ & 47 & $14.3 \%$ & 71 & $12.8 \%$ \\
\hline & $\$ 51$ to $\$ 74,000$ & 55 & $24.2 \%$ & 74 & $22.6 \%$ & 129 & $23.3 \%$ \\
\hline & $\$ 75,000$ to $\$ 100,000$ & 47 & $20.7 \%$ & 79 & $24.2 \%$ & 126 & $22.7 \%$ \\
\hline & $\$ 101,000$ to $\$ 150,000$ & 55 & $24.2 \%$ & 72 & $21.9 \%$ & 127 & $22.8 \%$ \\
\hline & $\$ 151,000$ or more & 46 & $20.3 \%$ & 56 & $16.8 \%$ & 102 & $18.4 \%$ \\
\hline \multicolumn{8}{|l|}{ Family Status: } \\
\hline & Single person, no children & 111 & $48.9 \%$ & 153 & $46.7 \%$ & 264 & $47.6 \%$ \\
\hline & Single person, with children & 15 & $6.6 \%$ & 27 & $8.2 \%$ & 42 & $7.6 \%$ \\
\hline & Married/De facto, no children & 30 & $13.2 \%$ & 48 & $14.6 \%$ & 78 & $14.0 \%$ \\
\hline & Married/De facto, with children & 71 & $31.3 \%$ & 100 & $30.5 \%$ & 171 & $30.8 \%$ \\
\hline
\end{tabular}

\subsection{Factors Affecting Consumer Opinion about Edible Insects}

The analysis identified several reasons which might shape people's opinions and attitudes about consuming edible insects. This section examines them one by one, using direct quotes from the surveys.

\subsubsection{Taste Factor}

First, tasting evaluation (i.e., sensory properties) is one of the key aspects in the consumer decision-making process for food products [46] and is mostly based on previous experience. In the absence of real experiences of eating edible insects, expected perception becomes a very strong factor in shaping what the taste might be.

There were a few participants $(n=10)$ in the surveys who mentioned having real experience with eating insects. These experiences were used by a small fraction of the respondents who are in favour of encouraging entomophagy, 10\% and 7\% in the 2018 and 2019 surveys, respectively (see Table 3).

Table 3. Tasting factors: real experience versus imagination of eating insects.

\begin{tabular}{|c|c|}
\hline Real Experience of Eating Insects & Expected Experience of Eating Insects \\
\hline $\begin{array}{l}\text { "I've been in India and Indonesia and I haven't } \\
\text { eaten many insects, but the ones I have tried } \\
\text { surprisingly for me were quite tasty. I think we } \\
\text { should reconsider our lack of interest for edible } \\
\text { insects and include them in our foods." (Male, } \\
35 \text { years) }\end{array}$ & $\begin{array}{l}\text { "I never tried them and never will do. No particular } \\
\text { reasons-just I can't open my mouth and put an insect } \\
\text { inside, even a chewable insect." (Female, } 19 \text { years) }\end{array}$ \\
\hline $\begin{array}{l}\text { "I love insects as I tried some in Cambodia a year } \\
\text { ago-not sure what was, crickets or some sorts of } \\
\text { larvae, but they were fried and crunchy. I think if } \\
\text { people know more about them and especially if } \\
\text { they taste them, they will love it." (Male, } 28 \text { years) }\end{array}$ & $\begin{array}{l}\text { "I don't think real insects to be used as part of our normal } \\
\text { diet will be accepted by our society. People are definitely } \\
\text { aware that they can eat them, but they can't put them in } \\
\text { their mouth." (Female, } 20 \text { years) }\end{array}$ \\
\hline
\end{tabular}


Table 3. Cont.

\begin{tabular}{ll}
\hline \multicolumn{1}{c}{ Real Experience of Eating Insects } & \multicolumn{1}{c}{ Expected Experience of Eating Insects } \\
\hline "Regarding insects, I have tried on holidays in \\
$\begin{array}{ll}\text { Asia, but never considered to make them part of } \\
\text { my diet. I'm not reluctant and don't think this is } \\
\text { weirder than eating other animals but I wouldn't } \\
\text { know where to buy them." (Male, 29 years) }\end{array}$ & $\begin{array}{l}\text { creatures. I imagine they are kind of crawling and flying } \\
\text { around. I don't believe they will be something easily } \\
\text { digestible for me and I will always have the feeling they } \\
\text { are moving inside me." (Female, 19 years) }\end{array}$ \\
\hline & "The name gives me an unpleasant sensation. It is not \\
“I have eaten crickets in fried rice in India and & [just] a feeling of something yucky you have to consume, \\
was crunchy and tasty." (Female, 36 years) & $\begin{array}{l}\text { but also the feeling something is creepily crawling inside } \\
\text { you after being wrongly swollen." (Female, 37 years) }\end{array}$ \\
\hline
\end{tabular}

\subsubsection{Psychological Factor}

The main categories identified under psychological factors affecting the consumption of edible insects are concerns about perceptions of masculinity, conspiracy theories, and the concept of neophobia and disgust. Some participants $(n=27)$ revealed perceptions that consuming edible insects is a great and unwanted threat to masculinity and manliness, often joined with a sense of fear (see Table 4). These concerns were expressed only by the male participants, all of whom were not in a position to contemplate replacing meat with insects (e.g., "real men eat meat and not insects").

Table 4. Psychological factor: masculinity.

\begin{tabular}{l} 
Masculinity Comments \\
\hline "Edible insects will be even worse than eating tofu or something like tofu. You will be not a real man if you \\
dare to eat insects." (Male, 22 years) \\
\hline "Meat is power, masculine strength I enjoy the most. Edible or not-edible insects are novelty for me but deeply \\
inside me I believe they are less masculine than meat." (Male, 32 years) \\
\hline "I am a man and I like the taste, the smell, the blood, if you want, of the real juicy meat, not the imitation." \\
(Male, 22 years) \\
"It is not [a] common thing in our culture to consume insects and also not so masculine thing to consider." \\
(Male, 23years)
\end{tabular}

A new trend which emerged in the 2019 Survey is that the social movement for eating insects is the result from some kind of a conspiracy, as referred to by $4 \%$ of the respondents (see Table 5). It is interesting to observe that several of the supporters of a "conspiracy theory" are also climate change deniers. Other voices cast doubts about eating insects based on a lack of open information and hidden profit-making business interests.

Table 5. Psychological factor: conspiracy theory.

\begin{tabular}{l} 
Conspiracy Theory \\
\hline "Why it is important for us to consume edible insects? I am sure that behind this idea stays some powerful \\
lobby group or an organisation that wants to promote their products. I am not buying it." (Female, 35 years) \\
\hline "There is something secretive behind pushing us suddenly to eat edible insects and other creatures." (Male, \\
35 years) \\
"I hope they are not planning to put insect-based ingredients in our meal options, sausages, burgers. \\
As consumers, we are less perturbed if the products are well-labelled and not hidden insect-based ingredients \\
are included." (Female, 40 years)
\end{tabular}

Most of the participants expressed highly negative associations with the idea of considering insects as food. Strong words, such as "disgust", "detestation", "revulsion", "dislike", "vomit", "nuisance", 
and "neophobia" were used (Table 6). For example, many people used the most basic expression for disliking food-yuck, and felt the need to repeat it (e.g., "yuck, yuck"). The 2019 Survey also generated two distinctive reasons for the feeling of disgust, namely, the inability to contemplate introducing an insect into one's mouth and a creepy-crawly feeling.

Table 6. Psychological factor: sense of disgust.

\begin{tabular}{l} 
Sense of Disgust \\
\hline "Insects, worms, larvae, crickets they are all nuisance that can't be forgotten as they always provoke negative \\
feelings, nausea and a big aversion." (Male, 22 years) \\
\hline "I am a bit neophobic and usually I am finding it difficult to accept new things and eating edible insects is [an] \\
extremely new thing for me and [I] would not try any insect-based products." (Male, 26 years) \\
\hline "Absolutely disgusting, yuck, pretty yuck. If I can think of edible insects I recall worms, larvae, bugs and \\
straight away I imagine that I have to eat some things that are eating rotten animal flesh." (Female, 25 years) \\
\hline "None of my close circle of friends is happy with the idea of eating edible insects, we all share negative feelings \\
about it." (Female, 22 years) \\
\hline "Edible insects are yuck often crawly, slimy, wet and crunchy. Yuck, yuck, yuck. I don't want even to look at \\
and touch them." (Male, 39 years)
\end{tabular}

\subsubsection{Health Factor}

The opinions around the health value of insects as a source of food were divided between those who believed that there was some nutritional value in this dietary choice and those who expressed safety concerns about the spread of diseases and other unhealthy impacts (Table 7). In total, there were more people who perceived positive benefits on human health $(n=33)$ than those who considered possible negative impacts $(n=10)$. Furthermore, some participants mentioned fear about their own health because of insects being a dangerously unhealthy food option.

Table 7. Health factor.

\begin{tabular}{ll}
\hline \multicolumn{1}{c}{ Health Scare Associated } & \multicolumn{1}{c}{ Health Benefits Associated } \\
\hline $\begin{array}{l}\text { "Totally not so natural and healthy for humans, even [if] } \\
\text { they advertise it as natural and healthy." (Female, }\end{array}$ & $\begin{array}{l}\text { "Depends on nutrition edible insects and other } \\
\text { meat alternatives provide, they could be seen as } \\
\text { really good for human health." (Female, 24 years) }\end{array}$ \\
\hline $\begin{array}{ll}\text { "They offer edible insects, but no one is looking at the } \\
\text { possibilities of some outrageous outbreak that will need }\end{array}$ & $\begin{array}{l}\text { "They're maybe nutritious. I've heard insects } \\
\text { have some special vitamin and minerals and these } \\
\text { an urgent address. Maybe insects are not good for }\end{array}$ \\
$\begin{array}{ll}\text { humans." (Male, 23 years) } \\
\text { (Male, 26 years) }\end{array}$ \\
$\begin{array}{ll}\text { "I am really scared, and miserable thinking of the side } \\
\text { effects edible insects could cause to us humans." (Male, }\end{array}$ & $\begin{array}{l}\text { "Edible insects are probably better for the } \\
\text { environment and for your health in many ways." } \\
\text { (Male, 21 years) }\end{array}$ \\
\hline "I am sure they have some nasty bacteria, carry unknown & "I believe edible insects bring heaps of essential \\
diseases, some specific infections, absolutely no way for & $\begin{array}{l}\text { nutrients that are great for us humans." (Female, } \\
\text { me to consume them." (Male, 38 years) }\end{array}$ \\
\hline
\end{tabular}

In the 2019 Survey, there were many references to insects being consumed in non-Western countries as a healthy food choice. The reasons why edible insects may be good for human health ranged from their nutritional value as a source of protein, to containing fibre and other nutrients.

Broader sustainability considerations which link environmental and human health were also expressed. Nevertheless, there were still admissions of skepticism about insects as food, with respondents using words, such as "probably", "maybe", and "could be seen as really good". 


\subsubsection{Environment Factor}

The three main environmental factors which transpired through the direct quotes pertained to (1) less greenhouse gas emissions, (2) sustainable farming of insects, and (3) a better environment for the planet (Table 8). Quite a few of the respondents made the point that eating insects is a more sustainable option than current patterns of high meat consumption. These respondents appeared to be aware of the serious negative environmental impacts associated with livestock [47] and this forced them to make the comparison with entomophagy.

Table 8. Environmental factor.

\begin{tabular}{|c|c|c|}
\hline Greenhouse Gas Emissions & Sustainable Farming & Better Environment \\
\hline $\begin{array}{l}\text { "Insects I read produce only a } \\
\text { small fraction of greenhouse gases } \\
\text { which make them more } \\
\text { environmentally friendly than } \\
\text { other farm animals." (Male, } \\
22 \text { years) }\end{array}$ & $\begin{array}{l}\text { "Edible insects and other meat } \\
\text { alternatives are necessary to } \\
\text { consume for the environment, the } \\
\text { animal welfare and the resources } \\
\text { we need to raise animals." (Male, } \\
22 \text { years) }\end{array}$ & $\begin{array}{l}\text { "The idea of eating insects is } \\
\text { outrage but many will embrace it } \\
\text { as it's a solution for a better } \\
\text { environment." (Female, } 20 \text { years) }\end{array}$ \\
\hline $\begin{array}{l}\text { "This alternative is important as it } \\
\text { can help to reduce greenhouse } \\
\text { emissions, save animals and focus } \\
\text { on health." (Male, } 22 \text { years) }\end{array}$ & $\begin{array}{l}\text { "Edible insects are less land } \\
\text { consuming than traditional } \\
\text { farmed animals. They can } \\
\text { multiply quickly in small areas." } \\
\text { (Female, } 22 \text { years) }\end{array}$ & $\begin{array}{l}\text { "The meat processing industry is } \\
\text { affecting the world and } \\
\text { environment. New meat-free } \\
\text { products will help to change our } \\
\text { environment in the long term for } \\
\text { the good." (Female, } 20 \text { years) }\end{array}$ \\
\hline $\begin{array}{l}\text { "Necessary is any food that will } \\
\text { keep us alive and save the planet } \\
\text { from global warming, like insects." } \\
\text { (Female, } 22 \text { years) }\end{array}$ & $\begin{array}{l}\text { "Somewhat any edible insects are } \\
\text { fast growing and multiplying } \\
\text { which is good for securing } \\
\text { sufficient food in short period of } \\
\text { time." (Female, } 22 \text { years) }\end{array}$ & $\begin{array}{l}\text { "It is necessary to try new } \\
\text { alternatives to our traditional food } \\
\text { and meat, and check [the] impact } \\
\text { they have on the planet. We need } \\
\text { to create a better environment with } \\
\text { our food choices." (Male, } 26 \text { years) }\end{array}$ \\
\hline
\end{tabular}

\subsubsection{Marketing Factor}

Based on the work of Baker, Shin and Kim [48], the surveys linked the influence of marketing on individual consumer behaviour and food choices through two categories, namely, the visual and descriptive presentations of edible insects (Table 9).

Table 9. Marketing factors.

\begin{tabular}{|c|c|}
\hline Visual Presentation & Descriptive Presentation \\
\hline $\begin{array}{l}\text { "I think it's the same as eating weird things like oysters, } \\
\text { snails, mussels. Edible insects can taste very nice when } \\
\text { they are properly cooked and served in a pleasant for the } \\
\text { eyes way." (Female, } 39 \text { years) }\end{array}$ & $\begin{array}{l}\text { "Maybe if marketed as [a] good healthy thing to } \\
\text { have I could include some insect-based } \\
\text { ingredients, more likely flour or something else } \\
\text { that is not too visible what exactly it is." } \\
\text { (Female, } 22 \text { years) }\end{array}$ \\
\hline $\begin{array}{l}\text { "They could add some crunchiness to meat I believe, but } \\
\text { still we have to think of the way they are presented and } \\
\text { with this respect cricket flour could be a good option on } \\
\text { offer." (Female, } 36 \text { years) }\end{array}$ & $\begin{array}{l}\text { "I believe the nutritional benefits are essential } \\
\text { for me to decide to consume of not." (Male, } \\
36 \text { years) }\end{array}$ \\
\hline $\begin{array}{l}\text { "Visually insects are not the best-looking food but if } \\
\text { created in a nicer way they could be pleasant for people to } \\
\text { eat. To be accepted by people, it's all about how they are } \\
\text { presented." (Male, } 37 \text { years) }\end{array}$ & $\begin{array}{l}\text { "Palate pleasant presentation." (Female, } \\
40 \text { years) }\end{array}$ \\
\hline
\end{tabular}

The image of insects was a major concern in order to deal with the feeling of disgust and the sensory barrier identified earlier. For most of the participants, the presentation should essentially aim 
at hiding the visibility of the insect bodies so that the taste and eating experience become the dominant feature of these foods.

\subsection{Vegetarians and Entomophagy}

A recent study by Elorinne et al. [49] showed how vegans, non-vegan vegetarians, and omnivores hold different intention regarding eating insects. In particular, non-vegan vegetarians held the most positive attitude toward entomophagy, whereas vegans felt more strictly that it was morally wrong to include edible insects (i.e., meat consumption) as an eating practice. Interestingly, both non-vegan vegetarians and omnivores have the same opinions about the benefits of entomophagy as a possible solution to address malnutrition worldwide.

In our study, a small proportion of the two Sydney population samples were vegetarian- $8 \%$ in 2018 and 7\% in 2019. All vegetarians pointed out their concerns about the natural environment as being at the heart of the justification for insect-based food alternatives, particularly in comparison to traditional meat production. They also linked it to greenhouse gas emissions as a way that "could be used to combat the planet's current and imminent climate change situation" (Table 10).

Table 10. Vegetarians about eating insects, 2019 Survey.

\footnotetext{
"Although I don't consume meat I think it is important to consider insects as an option as they are grass-feeder and also our population will be getting larger and larger, and our only and necessary choice apart from our current food will be to choose insects. That is why I think that we all should consider eating insects." (Male, 40 years)

"I am vegetarian, not so strict as I am eating cheese and eggs, but I believe we need the edible insects as solution to reduce the environmental problems caused by livestock production and intense factory farming." (Female, 21 years)

"Edible insects and incest-based products are an interesting alternative to meat. Of course, it is far away from an option for a vegan like me but for many people consuming lots of meat will be [a] very good alternative and maybe [a] healthier alternative. It will contribute to the climate change agenda." (Female, 18 years)
}

\section{Discussion}

This study contributes new methods and new insights into the attitudes of young Australian consumers about entomophagy. In terms of methods, we utilised a large sample of respondents who answered open-ended questions, a technique not commonly used in other research on this topic. Such an approach was able to provide data with new understanding on the words and expressions associated with insect-eating and how they create broader opinions. By using this qualitative approach, some new insights (e.g., the roles of conspiracy theory and masculinity) emerged.

Overall, our findings suggest that even people who have expressed a willingness to try edible insects are highly unlikely to change their current preferred meat-based diets (e.g., "I know it is important for the sustainability but I rather decrease my other consumption than replacing it with insects"). Interestingly, no specific link between the current frequency of meat consumption and the openness to try entomophagy emerged.

Besides eating habits, culture, history, and geography play a significant role in how edible insects are perceived in different societies [22,48]. First, as previous studies showed [35,50], many respondents believe that their relatives and close friends would not consider eating insects and would regard it as a "weird practice". Therefore, it seems clear that the role of social acceptance by peers and aquaintances is a significant predictor of willingness to try insects [51] and should be considered vital to increase acceptance (e.g., "I will try them as they were safely eaten by many people around the world").

As mentioned in the introduction, eating insects today is not considered part of the Australian diet, but entomophagy has always been present in the history of this place. Aboriginal people used to eat termites and grubs long before the British settlement in Oceania [22] and many continue to maintain this tradition. However, within the country's present complex cultural landscape, eating 
insects has not gained any popularity. Only one participant in our sample referred to the witchetty grub traditional practices of Aboriginal Australians consisting of consuming the wood-eating larvae of more than twenty species of moths [52] whose taste is described to be similar to scrambled eggs.

Our findings confirmed the role of psychological factors as being among the main barriers for acceptance. Most respondents reacted with disgust at the idea of ingesting living creatures that are associated with "eating rotten animal flesh" and other negative images. Disgust is commonly considered a basic emotion [53], a severe feeling of dislike, which is strongly culturally influenced [54]. However, disgust is not literally equivalent to "bad taste" but is mostly shaped by beliefs about the nature or origin of the food, rather than the actual perceptual qualities. Disgust or sensitivity is also found to be strictly related to food neophobia and might be a barrier to the acceptance of new food [55]. Many recent studies $[14,56,57]$ clearly indicate how the individual trait of food neophobia significantly and negatively affects the intention to taste and eat an insect-based product.

Such concerns suggest that education strategies should strengthen the difference between insects as food and the "moving", "crawling", and "flying" creatures in nature which people in the West associate with the term. We noticed, for example, the misconstrued perceptions that only insects are "moving creatures" and that people do not make such an association with common farmed animals. This may be explained by the idea that Western consumers typically think of insects as a pest rather than food. A few respondents expressed their concerns about communicable diseases that could be spread or transmitted by insects ("insects and especially crickets are pest[s] and are bad for our human health"). Therefore, it would be appropriate, before introducing insects in the food market, to start educating the population that edible insects, if properly processed, are a legitimate food source [48].

We also found that younger respondents (e.g., Generation Z) were more willing to try edible insects based on better awareness about the environmental benefits of using this protein source compared to animal-based products. This should be taken into consideration by the industry and integrated with "socially responsible marketing," which takes into consideration the broader social good [58], especially if the targeted consumers are environmentally conscious.

Moreover, the influence of the exisitng food culture is often not as strong among younger people than it is among older individuals. For people who already have an established diet, it will be more difficult to successfully change their habits and challenge rooted norms. In addition, our findings show that the perceived threat to masculinity is one barrier for the acceptance of this new food source as a meat replacement.

From a marketing point of view, our findings may help to better understand different target segments of potential customers in retail settings. Similar to the study by Baker et al. [48] for the US population, Australians who are more likely to try edible insects could be labelled by their segments of health and environmental conscious. For instance, people who considered eating insects a positive option as "the food of the future" based their justification predominantly on sustainability benefits in terms of land use, pressure on natural resources, and climate change vulnerability. Contrastingly, people who are climate change deniers are more likely to consider initiaves that encourage eating insects to be "conspiracy theories" which is a new finding not covered by previous studies. Regarding health conscious consumers, based on previous literature [51], descriptive information which communicates nutritional benefits is likely to have an effect only on people highly interested in health.

Yet, even if nutritional values and environmental concerns are often used to promote insect-eating, it is important to consider how taste attributes are relevant to the overall acceptance [59]. Our study confirmed the results of Wilkinson et al. [28], who suggest that Australian consumers would be more open if insects were processed and incorporated into familiar products (e.g., bakery products). This finding is also confirmed by other studies in Europe which show how familiarity with novel food might increase the appeal and likelihood of repeating the behavior $[3,34,50,57,60]$. Therefore, culinary innovation to create tasty insect-based food products with high sensory appeal may be a successful strategy to change negative beliefs and increase acceptance [48]. 
Most respondents found edible insects to be considered disgusting, associated with contamination and health risk, such as diseases and allergic reactions [39]. However, a previous study by Lensvelt and Steenbekkers [26] shows that when insects were proposed as a food in a tasting session the participants did not think eating them posed risks to their health.

Interestingly, some respondents pointed out that consuming insects can be experienced as extreme (or unnecessary) food choices when other options exist. A few of them, mostly males, perceived eating insects as a way to rebel against existing practices. This is understandable given the age groups covered in this survey and the fact that younger generations are more inclined to challenge any status quos.

In contrast with some previous studies which have indicated that women have higher insect aversions than men [50,51], the gender effect was not found to be of significant importance. There were no substantial differences between men and women in developing opinions towards the acceptance of insects as food.

\section{Conclusions}

Only recently have Western countries faced the possibility of eating insects [13] and a number of studies has focused on consumers' perceptions and acceptance of such novel foods [24]. Our study aimed at understanding opinions about eating edible insects and insect-based products among a group of younger Australian adults.

Even if edible insects are considered one of the more sustainable responses to the increased need for animal-based protein, there is still a relatively low general readiness to adopt entomophagy as a meat substitute practice [51]. Our study suggests that there is strong prejudice and a lack of knowledge about edible insects among Sydney's residents which is reflected in the low willingness to consume them. Thereby, education and a less scary/shocking communication style by the media might help to reduce prejudice and increase consumers' knowledge about insects as food, including an understanding of how to prepare and consume them $[4,26,61]$.

However, the idea of edible insects as a food source might grow more prominent as young people become more aware of sustainability and climate change issues related to food production and consumption, as has been the case in recent years. In addition, including insect food products in diets will also depend on their availability, as well as familiarity and taste.

Therefore, further qualitative studies should take into consideration the use of images and/or the tasting of real products during interviews. These techniques can help contribute to a more realistic context of insect consumption and gather more accurate behaviour and views towards this practice. Moreover, for the specific context of Australia, it would be interesting to investigate how the history and food culture of eating insects by Indigenous people are influencing the current perceptions about this practice.

Author Contributions: Although this work is the result of a common effort, G.S. was responsible for the supervision of the work and took the lead in organising the structure of the manuscript. In specific, G.S. conceived and wrote the introduction and Section 2. D.B. and D.M. contributed to the data collection analysis, and interpretation of results. All authors contributed to writing the Discussion and Conclusion sections and to critically reviewing and editing the manuscript. All authors read and approved the final version.

Funding: This research received no external funding.

Conflicts of Interest: The authors declare no conflict of interest.

\section{References}

1. Food and Agriculture Organization of the United Nations. The State of Food and Agriculture. Leveraging Food Systems for Inclusive Rural Transition. 2017. Available online: http://www.fao.org/3/a-i7658e.pdf (accessed on 20 March 2019).

2. Belluco, S.; Halloran, A.; Ricci, A. New protein sources and food legislation: The case of edible insects and EU law. Food Secur. 2017, 9, 803. [CrossRef] 
3. Cavallo, C.; Materia, V.C. Insects or not Insects? Dilemmas or Attraction for Young Generations: A Case in Italy. Int. J. Food Syst. Dyn. 2018, 9, 226-239.

4. Dobermann, D.; Swift, J.A.; Field, L.M. Opportunities and hurdles of edible insects for food and feed. Nutr. Bull. 2017, 42, 293-308. [CrossRef]

5. Hartmann, C.; Siegrist, M. Consumer perception and behaviour regarding sustainable protein consumption: A systematic review. Trends Food Sci. Technol. 2017, 61, 11-25. [CrossRef]

6. Oonincx, D.G.A.B.; van Itterbeeck, J.; Heetkamp, M.J.W.; van den Brand, H.; van Loon, J.J.A.; van Huis, A. An Exploration on Greenhouse Gas and Ammonia Production by Insect Species Suitable for Animal or Human Consumption. PLoS ONE 2011, 5, e14445. [CrossRef]

7. Leip, A.; Billen, G.; Garnier, J.; Grizzetti, B.; Lassaletta, L.; Reis, S.; Westhoek, H. Impacts of European livestock production: Nitrogen, sulphur, phosphorus and greenhouse gas emissions, land-use, water eutrophication and biodiversity. Environ. Res. Lett. 2015, 10, 115004. [CrossRef]

8. Tilman, D.; Clark, M. Global diets link environmental sustainability and human health. Nature 2014, 515, 518-522. [CrossRef]

9. Van Huis, A. Potential of Insects as Food and Feed in Assuring Food Security. Annu. Rev. Entomol. 2013, 58, 563-583. [CrossRef]

10. van Huis, A. Edible insects are the future? Proc. Nutr. Soc. 2016, 75, 294-305. [CrossRef]

11. Conti, C.; Costa, A.; Balzaretti, C.; Russo, V.; Tedesco, D. Survey on Food Preferences of University Students: From Tradition to New Food Customs? Agriculture 2018, 8, 155. [CrossRef]

12. House, J. Insects are not 'the new sushi': Theories of practice and the acceptance of novel foods. Soc. Cult. Geogr. 2018, 9365, 1-22. [CrossRef]

13. van Huis, A.; Van Itterbeeck, J.; Klunder, H.; Mertens, E.; Halloran, A.; Muir, G.; Vantomme, P. Edible insects. In Future Prospects for Food and Feed Security; Food and Agriculture Organization of the United Nations: Rome, Italy, 2013; Volume 171.

14. Hartmann, C.; Siegrist, M. Becoming an insectivore: Results of an experiment. Food Qual. Prefer. 2016, 51, 118-122. [CrossRef]

15. Sogari, G.; Liu, A.; Li, J. Understanding Edible Insects as Food in Western and Eastern Societies. In Environmental, Health, and Business Opportunities in the New Meat Alternatives Market; Bogueva, D., Marinova, D., Raphaely, T., Schmidinger, K., Eds.; IGI Global: Hershey, PA, USA, 2019; pp. 166-181. [CrossRef]

16. Rumpold, B.A.; Schluter, O.K. Nutritional composition and safety aspects of edible insects. Mol. Nutr. Food Res. 2013, 57, 802-823. [CrossRef]

17. Payne, C.L.R.; Scarborough, P.; Rayner, M.; Nonaka, K. A systematic review of nutrient composition data available for twelve commercially available edible insects, and comparison with reference values. Trends Food Sci. Techol. 2016, 47, 69-77. [CrossRef]

18. van Huis, A.; Oonincx, D.G.A.B. The environmental sustainability of insects as food and feed. A review. Agron. Sustain. Dev. 2017, 37, 43. [CrossRef]

19. Gasco, L.; Finke, M.; Van Huis, A. Can diets containing insects promote animal health? J. Insects Food Feed 2018, 4, 1-4. [CrossRef]

20. van der Spiegel, M.; Noordam, M.Y.; van der Fels-Klerx, H.J. Safety of novel protein sources (insects, microalgae, seaweed, duckweed, and rapeseed) and legislative aspects for their application in food and feed production. Compr. Rev. Food Sci. Food Saf. 2013, 12, 662-678. [CrossRef]

21. Van Huis, A.; Dunkel, F.V. Edible Insects: A Neglected and Promising Food Source. In Sustainable Protein Sources; Elsevier Inc.: Amsterdam, The Netherlands, 2016; pp. 341-355. [CrossRef]

22. Lesnik, J. Edible Insects and Human Evolution; Project MUSE; University Press of Florida: Gainesville, FL, USA, 2018.

23. Meyer-Rochow, V.B.; Changkija, S. Uses of insects as human food in Papua New Guinea, Australia, and North-east India: Cross-cultural considerations and cautious conclusions. Ecol. Food Nutr. 1997, 36, $159-185$. [CrossRef]

24. Jongema, Y. List of Edible Insects of the World. Available online: https://www.wur.nl/en/Research-Results/ Chair-groups/Plant-Sciences/Laboratory-of-Entomology/Edible-insects/Worldwide-species-list.htm (accessed on 1 April 2017).

25. Mancini, S.; Moruzzo, R.; Riccioli, F.; Paci, G. European consumers' readiness to adopt insects as food. A review. Food Res. Int. 2019. [CrossRef] 
26. Lensvelt, E.J.S.; Steenbekkers, L.P.A. Exploring Consumer Acceptance of Entomophagy: A Survey and Experiment in Australia and the Netherlands. Ecol. Food Nutr. 2014, 53, 543-561. [CrossRef]

27. Myers, G.; Pettigrew, S. A qualitative exploration of the factors underlying seniors' receptiveness to entomophagy. Food Res. Int. 2018, 103, 163-169. [CrossRef] [PubMed]

28. Wilkinson, K.; Muhlhausler, B.; Motley, C.; Crump, A.; Bray, H.; Ankeny, R. Australian Consumers' Awareness and Acceptance of Insects as Food. Insects 2018, 9, 44. [CrossRef]

29. Lähteenmäki-Uutela, A.; Hénault-Ethier, L.; Marimuthu, S.B.; Talibov, S.; Allen, R.N.; Nemane, V.; Vandenberg, G.W.; Józefiak, D. The impact of the insect regulatory system on the insect marketing system. J. Insects Food Feed 2018, 4, 187-198. [CrossRef]

30. Lähteenmäki-Uutela, A.; Grmelova, N.; Henault-Ethier, L.; Deschamps, M.H.; Vandenberg, G.W.; Zhao, A.; Zhang, Y.; Yang, B.; Nemane, V. Laws of the European Union, United States, Canada, Mexico, Australia, and China. Eur. Food Feed Law Rev. (EFFL) 2017, 12, 22-36.

31. Sogari, G.; Amato, M.; Biasato, I.; Chiesa, S.; Gasco, L. The Potential Role of Insects as Feed: A Multi-Perspective Review. Animals 2019, 9, 119. [CrossRef]

32. Food Standards Australia New Zealand Regulation of Novel Foods. 2017. Available online: http://www. foodstandards.gov.au/industry/novel/Pages/default.aspx (accessed on 20 March 2019).

33. Webb, C. Does it bug you? Edible insects on the menu at Royal Melbourne Show. The Age. 23 September 2018. Available online: https://www.theage.com.au/national/victoria/does-it-bug-you-edible-insects-on-themenu-at-royal-melbourne-show-20180923-p505j6.html (accessed on 20 March 2019).

34. Caparros Megido, R.; Sablon, L.; Geuens, M.; Brostaux, Y.; Alabi, T.; Blecker, C.; Francis, F. Edible insects acceptance by Belgian consumers: Promising attitude for entomophagy development. J. Sens. Stud. 2014, 29, 14-20. [CrossRef]

35. Sogari, G.; Menozzi, D.; Mora, C. Sensory-liking expectations and perceptions of processed and unprocessed insect products. Int. J. Food Sys. Dyn. 2018, 9, 314-320. [CrossRef]

36. Schouteten, J.J.; De Steur, H.; De Pelsmaeker, S.; Lagast, S.; Juvinal, J.G.; De Bourdeaudhuij, I.; Gellynck, X. Emotional and sensory profiling of insect-, plant- and meat-based burgers under blind, expected and informed conditions. Food Qual. Prefer. 2016, 52, 27-31. [CrossRef]

37. Tan, H.S.G.; Fischer, A.R.; van Trijp, H.C.; Stieger, M. Tasty but nasty? Exploring the role of sensory-liking and food appropriateness in the willingness to eat unusual novel foods like insects. Food Qual. Prefer. 2016, 48, 293-302. [CrossRef]

38. Bogueva, D.; Schmidinger, K. Normality, Naturalness, Necessity, and Nutritiousness of the New Meat Alternatives. In Environmental, Health, and Business Opportunities in the New Meat Alternatives Market; Bogueva, D., Marinova, D., Raphaely, T., Schmidinger, K., Eds.; IGI Global: Hershey, PA, USA, 2019; pp. 20-37. [CrossRef]

39. Castro, M.; Chambers, E. Willingness to eat an insect based product and impact on brand equity: A global perspective. J. Sens. Stud. 2018, e12486. [CrossRef]

40. Chan, E.Y. Mindfulness and willingness to try insects as food: The role of disgust. Food Qual. Prefer. 2019, 71, 375-383. [CrossRef]

41. Fowler, F.J. Survey Research Methods, 2nd ed.; SAGE: Thousand Oaks, CA, USA, 1993.

42. Ary, D.; Jacobs, L.; Razavieh, A. Introduction to Research in Education; Holt, Rinehart, and Winston: Fort Worth, TX, USA, 1996.

43. NVivo Qualitative Data Analysis Software; Version 11; QSR International Pty Ltd.: Melbourne, Australia, 2017.

44. Marinova, D.; Bogueva, D. Planetary health and reduction in meat consumption. Sustain. Earth $2019,2,3$. [CrossRef]

45. Roy Morgan. The Slow But Steady Rise of Vegetarianism in Australia. 2016. Available online: http: //www.roymorgan.com/findings/vegetarianisms-slow-but-steady-rise-in-australia-201608151105 (accessed on 20 March 2019).

46. Cunha, L.M.; Cabral, D.; Moura, A.P.; de Almeida, M.D.V. Application of the Food Choice Questionnaire across cultures: Systematic review of cross-cultural and single country studies. Food Qual. Prefer. 2018, 64, 21-36. [CrossRef]

47. Raphaely, T.; Marinova, D. (Eds.) Impact of Meat Consumption on Health and Environmental Sustainability; IGI Global: Hershey, PA, USA, 2016. 
48. Baker, M.A.; Shin, J.T.; Kim, Y.W. Customer Acceptance, Barriers, and Preferences in the U.S. In Edible Insects in Sustainable Food Systems; Halloran, A., Flore, R., Vantomme, P., Roos, N., Eds.; Springer International Publishing: Cham, Switzerland, 2018; pp. 387-399. [CrossRef]

49. Elorinne, A.L.; Niva, M.; Vartiainen, O.; Väisänen, P. Insect Consumption Attitudes among Vegans, Non-Vegan Vegetarians, and Omnivores. Nutrients 2019, 11, 292. [CrossRef] [PubMed]

50. Menozzi, D.; Sogari, G.; Veneziani, M.; Simoni, E.; Mora, C. Eating novel foods: An application of the Theory of Planned Behaviour to predict the consumption of an insect-based product. Food Qual. Prefer. 2017, 59, 27-34. [CrossRef]

51. Hartmann, C.; Shi, J.; Giusto, A.; Siegrist, M. The psychology of eating insects: A cross-cultural comparison between Germany and China. Food Qual. Prefer. 2015, 44, 148-156. [CrossRef]

52. Bock, D.; Atkins, B. Witchetty Grubs, Australian Museum. 2018. Available online: https://australianmuseum. net.au/learn/teachers/learning/bugwise/witchetty-grubs/ (accessed on 20 March 2019).

53. Ekman, P.; Friesen, W.V. Constants across cultures in the face and emotion. J. Personal. Soc. Psychol. 1971, 17, 124-129. [CrossRef]

54. Piha, S.; Pohjanheimo, T.; Lähteenmäki-Uutela, A.; Křečková, Z.; Otterbring, T. The effects of consumer knowledge on the willingness to buy insect food: An exploratory cross-regional study in Northern and Central Europe. Food Qual. Prefer. 2018. [CrossRef]

55. Hartmann, C.; Siegrist, M. Development and validation of the Food Disgust Scale. Food Qual. Prefer. 2018, 63, 38-50. [CrossRef]

56. La Barbera, F.; Verneau, F.; Amato, M.; Grunert, K. Understanding Westerners' disgust for the eating of insects: The role of food neophobia and implicit associations. Food Qual. Prefer. 2018, 64, 120-125. [CrossRef]

57. Sogari, G.; Menozzi, D.; Mora, C. The food neophobia scale and young adults' intention to eat insect products. Int. J. Consum. Stud. 2019, 43, 68-76. [CrossRef]

58. Bogueva, D.; Marinova, D.; Raphaely, T. Handbook of Research on Social Marketing and Its Influence on Animal Origin Food Product Consumption; IGI Global: Hershey, PA, USA, 2018.

59. Elhassan, M.; Wendin, K.; Olsson, V.; Langton, M. Quality Aspects of Insects as Food-Nutritional, Sensory, and Related Concepts. Foods 2019, 8, 95. [CrossRef] [PubMed]

60. Verneau, F.; La Barbera, F.; Kolle, S.; Amato, M.; Del Giudice, T.; Grunert, K. The effect of communication and implicit associations on consuming insects: An experiment in Denmark and Italy. Appetite 2016, 106, 30-36. [CrossRef] [PubMed]

61. Baker, M.A.; Shin, J.T.; Kim, Y.W. An Exploration and Investigation of Edible Insect Consumption: The Impacts of Image and Description on Risk Perceptions and Purchase Intent. Psychol. Mark. 2016, 33, 94-112. [CrossRef]

(C) 2019 by the authors. Licensee MDPI, Basel, Switzerland. This article is an open access article distributed under the terms and conditions of the Creative Commons Attribution (CC BY) license (http://creativecommons.org/licenses/by/4.0/). 